\title{
Wage and Resistance
}

\author{
Eric Lott
}

The real deal on wage work and its discontents first came home to historian Robin Kelley on the fast-food shopfloor of a central Pasadena Mickey D's. Everyday life in the happy place meant compulsory quickness and forced smiles, heinous swing managers, racist patrons, and unbearable polyester uniforms - as well as casually inventive ways to beat the rap. McDonaldland cookies were liberated by the boxfull, $\mathrm{CP}$ time was in full effect and industrial sabotage (whoops - shake machine busted) was not unheard of. "But what I remember most," writes Kelley in Race Rebels: Culture, Politics, and the Black Working Class, "was the way many of us stylized our work. We ignored the films and manuals and turned work into performance." Women smoothly operated the register with elegant nails and prodigious finger rings. Tossing trash like Dr. J and working the grill with spatula-microphones offered exemplary ways to swing the shift. "And while all of this was going on, folks were signifying on one another, talking loudly about each other's mommas, daddys, boyfriends, girlfriends, automobiles (or lack thereof), breath, skin colour, uniforms; on occasion describing in hilarious detail the peculiarities of customers standing on the other side of the counter."

Not much in this steady prole-playing to satisfy conventional ideals of developed political resistance - no organized wage demands or struggles over the work process, just punching in for your buddy, refusing that hairnet, taking it way light, and insisting 
on FM station FUNK. Such ubiquitous subterranean struggles for autonomy, pleasure, and community barely count in common definitions of working-class politics, but as Kelley argues, it's the definitions that have to change, not the struggles, which crucially underlie more organized forms of resistance and in themselves constitute the day-to-day dissent of everyday people in the grave world of dirt-wage capitalism.

Many have written off this quite unwavering commitment to the reinvention of work as hopelessly primitive rebellion, as "prepolitical" lumpen immaturity. Doing so ignores a whole historical realm of black working-class making and remaking, of self-consciousness and determined self-activity. As the uniquely unorthodox Marxist thinker C.L.R. James and his comrades once observed, "ordinary working people in factories, mines, fields and offices are rebelling every day in ways of their own invention. Sometimes their struggles are on a small personal scale...Always the aim is to regain control over their own conditions of life and their relations with one another. Their strivings have few chroniclers." When these lines were published in the 1958 pamphlet, Facing Reality, one could count James' own The Black Jacobins: Toussaint L 'Ouverture and the San Domingo Revolution (1938) and W.E.B. Du Bois's Black Reconstruction in America 1860-1880 (1935) as among the few chronicles to attend seriously to the small and large revolutionary strivings by black working people themselves to transform oppressive social orders.

Of course, in 1958 an uprising of historians echoing that of the earth's wretched was gathering force, soon issuing in a bolt of workers' studies by E.P. Thompson, Eugene Genovese, Harry Braverman, and many others that demonstrated the power of writing and acting upon history from below. The recent vogue of James's work - anthologies, critical studies, the posthumous publication of his 1950 volume, American Civilization - suggests an overdue recognition of James's enormous contribution to this view of history. But as Kelley's Race Rebels implicitly demonstrates, the embrace of James also suggests a renewed interest in the furtive, hidden, or unrecognized rebellions sometimes left out of 
even the "new social history" as well as, perhaps paradoxically, interest in the institutional questions James, the sometime Trotskyist, thought such rebellions raised. Reading James in tandem with Kelley opens to view a black workers' world neglected by writers and activists of many stripes despite its endlessly creative attempts to make history, in the margins but on its own terms.

Kelley calls these workers race rebels because they've often broken the rules of black activism no less than those of white revanchism. Like Kelley's earlier book, Hammer and Hoe: Alabama Communists During the Great Depression, (1990) Race Rebels parses black working people's radical acts and cultural proclivities both in their own communities and in relation to white workers' demands and militant organizations. Much more than its predecessor, though, Race Rebels seeks out a "hidden transcript" of defiance - "from footdragging to sabotage, theft at the workplace to absenteeism, cursing to graffiti" - that comprises what Kelley calls "history from way, way below." Kelley recounts an array of skirmishes between black workers and white overseers to indicate not only the untold ways in which workers fought back but what they fought about. Black domestic workers scorched or spat on the meals they made for white employers, or "pan-toted" leftover food and redundant utensils, as a way of compensating for miserable wages and work conditions, they did piece work or laundry in their own homes so as to avoid occupational hazards like demeaning uniforms and routine sexual harassment. Tobacco stemmers covered for ill coworkers rather than call incriminating attention to their condition, and on the factory floor, though talking or congregating was prohibited, workers would bust a note in unison to alleviate the toil. Working racist common sense about black laziness and ineptitude to their advantage, laborers might put on the mask, grinning and shuffling their way to a more comfortable pace. As DuBois said in Black Reconstruction about the widespread notion that blacks malingered at their work: "Of course they did ... It was the answer of any group of laborers forced down to the last ditch. They might be made to work continuously but no power could make them work well." Commending this moral economy of 
the lazy and larcenous, Kelley enjoins the shiftless of the world to unite.

The dignity, control, and collective will sought after in Kelley's hidden transcript surfaced in extremely various and sometimes confounding ways. For example, the adoption of spiritual values by black workers to combat class and racial ills - never mind the hostility or indifference of black churches to organized labor leads Kelley, characteristically, to revel in the contradiction rather than dismiss it as false consciousness: "How do we interpret divine intervention, especially when one's prayers are answered? How does the belief that God is by one's side affect one's willingness to fight with police, leave an abusive relationship, stand up to a foreman, participate in a strike, steal, or break tools?' Kelley's not particularly forthcoming with answers to these questions, but it's telling and to his credit that he asks them. And he is wonderful on the illicit pleasures of black working-class nightlife and the way black bodies beaten down during a week's work are in every sense recuperated through the collective exuberance of the dance floor and blues club.

One of Race Rebel's most striking set pieces surveys the constant, intimate insurrections aboard Southern streetcars and buses in the 1940s and 1950s. In Kelley's account, these "moving theatres," situated at the intersection of public and private space of performance and combat, of Southern manners and brute facts of racial ranking, hosted a protracted war over the placement and definition of the color line. White transit operators, notoriously racist, regularly short-changed black passengers (when they took the trouble to pick them up), made liberal use of blackjacks and pistols, and policed their cars with apartheid vigilance. In response, black passengers skilfully and courageously fucked with Jim Crow. They occupied "white" seats or refused to relinquish theirs to white riders, they openly ridiculed white passengers and operators, they cursed, they menaced, they "loud-talked," and when push came to shove, men and women both fought back. Such dramaturgical defiance was only a heightened instance of the jockeying for space and respect Kelley finds in many quarters. 
Those sceptical of spontaneous rebellion or cultural studies or both will ask about the value of such activities for "real," organized politics. How far and in what way do such struggles "count?" Adolf Reed Jr. in the Village Voice not long ago rebuked an article Kelley wrote for the Journal of American History for its alleged overvaluing of small local opposition, its substitution of culture for politics, and its inevitabilism (or complacency) regarding practical political mobilization. Kelley insists that subterranean and overt forms of resistance, as "two sides of the same coin that make up the history of working-class resistance," can't be "studied separately and then compared." Social movements, argues Kelley, are successful precisely to the extent that they articulate the "grievances, aspirations, and dreams" circulating in the "hidden transcript," while the latter, though fundamental to political mobilizations, only there finds its full radical realization. Still, with work relations structuring but certainly not preempting a whole variety of black working-class investments, Kelley suggests it would be a mistake to take trade unions or other labor institutions as the "real" harbingers of proletarian politics, even for organized labor militants. Trying to "make sense of people where they are rather than where we would like them to be," he insists that "for a worker to accept reformist trade union strategies while stealing from work, to fight streetcar conductors while voting down strike action in one's local, to leave work early in order to participate in religious revival meetings or rendezvous with one's lover, or to choose to attend a dance rather than a CIO mass meeting is not necessarily a sign of an 'immature' class consciousness"' but rather of black working people's complex ensemble of opposition then and now.

The most direct demonstrations of such propositions come in Kelley's chapters on the style politics of the young Malcolm X and the relation of the black working class to 1960s civil rights activism. Reading beyond the public script (in the Autobiography) of radical Malcolm's scorching self-indictment for his youthful indiscretions (zoot suit and conk, hustling and thieving), Kelley locates in them a militant logic that actually informed rather than deformed the mature Malcolm's political posture. Where Malcolm was 
forced by the spartan rigors of political-religious conversion in the Nation of Islam to disavow his earlier activities, Kelley speculated on what Ralph Ellison in the early 1940s called the "riddle of the zoot." Zoot suits used so much material to achieve their "drape shape" that they violated the War Production Board's cloth rationing, which was undoubtedly part of the suit's appeal; so was the association of sharkskin with untamed black and Chicano youth. In the roiling context of 1940s black militancy, including the "Double V" campaign (victory over Jim Crow at home as well as Hitler abroad), such style signified - white servicemen regularly made vigilante attacks on zoot suiters, and in 1943 the L.A. City Council considered making the wearing of zoot suits a misdemeanour. Malcolm's later commitments only shifted this social logic into a more explicit and mass-based register. Kelley likewise shows the opposition to wage labor and to the sanctity of private property contained in Malcolm's participation in an illicit economy, an opposition that later compelled him to compare capitalism to organized crime and to defend the looting by black working people in the Harlem riot of 1964. As Kelley acerbically remarks, Malcolm did not learn these lessons in the NOI.

For me, such connections don't trivialize the political so much as illuminate the conditions of its organized emergence. In Kelley's hands, Birmingham cultural studies makes perfect sense in Birmingham, Alabama, and enriches a history of struggle too often reduced to pious narratives of lonely heroism - Rosa Parks (who remains a hero) standing in for the extensive wars over public transport, or Martin Luther King for the civil rights struggles that, as Kelley shows, owe much to intraracial class negotiations. Kelley acutely reads the manner in which Birmingham's poor, unrepresented by the aspirations of the Southern Christian Leadership Conference, took to the streets in armed insurgency, flouting respectable race leaders and mocking the canons of nonviolent protest. Ultimately such collective urgency pushed the civil rights movement in a more militant and working-class direction, as in its calls for a check on police brutality, something not previously on the radar screen of middle-class activists. 
While Kelley nicely troubles some twice-told tales about the domain of politics, he does finesse the organizational issue a bit, especially regarding the relation of black resistance to the white left. Kelley includes two chapters on black activism within the ranks of the American Communist Party, implicit (because inexplicit) endorsements of black and white uniting and fighting. His study of radical black cultural politics within the CPUSA details the tensions of being black and red as much as the enabling autonomy white left organizations granted black writers and artists. Meanwhile, Kelley's exploration of African American involvement in the Spanish Civil War shows the irony of their link to this CP-inspired venture, which came about as a displaced response to Mussolini's invasion of Ethiopia. Just these strains were remarked by C.L.R. James himself. "Black and White, Unite and Fight is unimpeachable in principle," wrote James. "[B]ut it is often misleading and sometimes even offensive in the face of the infinitely varied, tumultuous, passionate, and often murderous reality of race relations in the United States."

Yet James, like Kelley after him, had the firmest faith in the eagerness of black people to be done with the organized thievery of capitalism: "Anyone who knows [the Negro people], who knows their history, is able to talk to them intimately, watches them at their own theatres, watches them at their dances, watches them in their churches, reads their press with a discerning eye, must recognize that ... the hatred of bourgeois society and the readiness to destroy it when the opportunity should present itself, rests among them to a degree greater than in any other section of the population in the United States." 